\title{
The Long and the Short of Missing Medicines
}

\author{
Denis Horgan $^{a}$ Robin Doeswijk ${ }^{b}$ \\ a European Alliance for Personalised Medicine, ${ }^{b}$ European Hematology Association, \\ The Hague, The Netherlands
}

\section{Keywords}

Shortage of medicine $\cdot$ Resources $\cdot$ Price $\cdot$ Cost $\cdot$ Access $\cdot$ Redistribution

\begin{abstract}
Who would have thought that in the most recent decade of the 21st century, shortages of medicines would be on the rise? As the authors will show, it is not simply about price, but involves other factors such as sudden outbreaks of a disease or diseases, a lack of raw materials, manufacturing issues and high demand. Shortages of medicines can lead to higher costs and lower quality and safety of care, while unavailable medicines tend to be substituted with often less effective medicines, which can even be more costly. Possible solutions involve a monitoring of supply chains and "early warning" systems as well as Member States getting together to purchase medicines as a group. There is no single answer, and there is much work to be done.

(C) 2017 The Author(s)

Published by S. Karger AG, Basel
\end{abstract}

\section{Tackling the Medicines Shortage}

One of the key issues affecting the health of European citizens today is a shortage of medicines. This is an EU-wide problem and there are many complex issues involved [1].

In the case of drugs for rare cancer patients, it can be as "simple" as high prices due to a, by definition, smaller market, so return on investment for pharmaceutical companies is difficult, if not impossible.

Even low profit margins can result in non-viable production lines, while so-called industry consolidation can lead to fewer older medicines which are often less profitable nowadays [2].

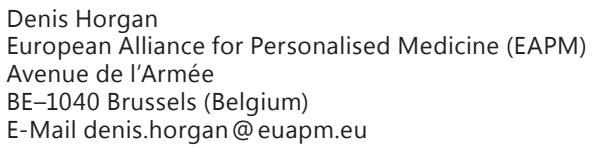


And, obviously, sudden health emergencies, for example large outbreaks of a certain disease or virus, can lead to shortages, often at a critical level.

But there are other factors, and the EU must face them as part of its moral duty and stated aim of giving the best healthcare possible, including more access and better diagnoses, for all 500 million citizens across the current 28 Member States [3].

One of the main pillars of the EU is equality for all, and surely there is no more important arena than that of healthcare.

The European Medicines Agency's (EMA) final common position on shortages, published several years ago and written in tandem with groups such as the European Organisation of Rare Diseases, the Pharmaceutical Group of the European Union, the European Public Health Alliance and others, defined supply shortage of medicine "as a situation in which the total supply of an authorised medicine or of a medicine used on a compassionate basis is inadequate to meet the current or projected demand at the patient level" [4].

"The shortage may be local, national, European or international," the document added.

The document also pointed out that Article 81 of the EU Directive on Medicines for Human Use was "intended to ensure adequate supply of any given product to the market. However, there is extensive evidence of situations where pharmacies can't obtain the medicines that they need for their patients".

In 2013, the EMA chose to establish a "public catalogue" of potential, ongoing and resolved shortages of medicines that are authorised at EU level, or that are being evaluated as part of a EU procedure.

Unfortunately, the catalogue does not give a complete overview of all medicine shortages occurring across the Union, because most shortages are dealt with at national level or exceed the EMA's mandate.

In the EU's favour is the fact that its Medicines Agencies Network Strategy up to 2020 has placed the availability of authorised medicinal products as a key public health priority.

\section{Shortages Affect Rich as well as Poor}

One major issue with shortages is that, while different EU countries have different levels of resources which can be a factor, medicine shortages happen in the richer as well as the poorer Member States. These can result from reasons as diverse as a lack of raw materials, manufacturing issues, high demand, basic economics and more besides [5].

Not only that, but the bench-to-bedside time scales (and costs) plus a lack of efficiency in the supply chain can lead to shortages. Then we have approval times and potential quality risks when there are attempts to speed these up [6].

Whatever the reason(s), shortages of medicines eventually lead to higher costs for the 28 healthcare systems operating individually under their own competence across the EU [7].

Shortages of vaccines, essentially to immunise children, are even occurring due to high demand and quality problems.

When it comes to patients, which is what it is all about, shortages can often mean lower quality and safety of care, with the added distress that these cause.

The shortages also mean that healthcare professionals are able to spend less time with their patients as they struggle to manage the shortage. Add to this the reality that unavailable medicines are often substituted with less effective and/or more expensive alternatives.

The latter incidence can lead to more medication errors due to a lack of familiarity with the replacement product, with the knock-on effect of more adverse reactions, worse patient outcomes and, in the worst case, even death.

It is clear that the potential negative consequences of a shortage can be huge [8]. 


\section{"Not an Ordinary Commodity"}

Unfortunately, reports of medicine shortages in the EU are on the rise, with all classes of medicines being affected. In a number of Member States, national authorities are now monitoring the situation, for example by setting up websites in order to inform the general public.

Also "advance notice systems" are often in place in a bid to mitigate the effects of shortages, and rely on data from medicine supply chains, but there is only so much that national medicines regulatory authorities can do as they cannot force a manufacturer to produce a certain medicine.

Monitoring the supply chain can help, as it allows for redistribution to areas of need. But this is usually at a national level only, as the EU does not have overall competency in this area [9].

Meanwhile, there have been calls for legislation that requires "early warning" to the EMA from companies about even a potential shortage, rather than the companies waiting for it to actually occur.

More recently, at an Informal Meeting of Health Ministers held in October of last year, under the Slovak Presidency of the EU, the background paper stated that: "Short and longterm shortages of medicinal products have been a global problem for the past decade and over the last few years it has also increasingly affected the EU."

It went on to state that shortages "have affected all classes of medicines including injectable chemotherapy agents, anaesthetic agents, intravenous nutrition, vaccines, electrolyte products, enzyme replacement products, radio-pharmaceuticals and more."

"Medicinal products are not an ordinary commodity and their unavailability is a serious problem as it may compromise patient care and can have a significant impact on the health systems of Member States," it added.

One of the conclusions cited regional cross-border cooperation, and the common purchasing of medicines, as part of any possible solutions. A similar plan is currently being tried by Belgium, Luxembourg and the Netherlands in the area of orphan drugs prices, so far with limited success [10].

However, it is clear that further cooperation is necessary between all stakeholders, including Member States, to make the problem of drug shortages a thing of the past.

\section{Disclosure Statement}

The authors have no conflicts of interest to declare.

\section{Funding Sources}

There are no funding sources.

\section{References}

1 EUR-Lex: Directive 2011/24/EU of the European Parliament and of the Council of 9 March 2011 on the application of patients' rights in cross-border healthcare. http://eur-lex.europa.eu/legal-content/EN/ TXT/?uri=celex:32011L0024.

2 Shire: Rare Disease Impact Report: insights from patients and the medical community. 2013. http://shirehgt. isebox.net/file/\%5B37458\%5D\%20RareDiseaseImpactReportforWeb.pdf?download (cited February 15, 2014). 
3 European Alliance for Personalised Medicine: Innovation and patient access to personalised medicine. 2013. http://euapm.eu/wp-content/uploads/2012/07/EAPM-REPORT-on-Innovation-and-Patient-Access-toPersonalised-Medicine.pdf (cited April 7, 2014).

-4 Clemens T, Michelsen T, Brand H: Supporting health systems in Europe: added value of EU actions? Health Econ Policy Law 2014; 9:49-69.

5 Council of the European Union: Council Conclusions on common values and principles in European Union health systems (2006) OJ C146/1. http://eur-lex.europa.eu/LexUriServ/LexUriServ.do?uri=0J:C:2006:146: 0001:0003:EN:PDF.

6 European Commission: White Paper: Together for Health: A Strategic Approach for the EU, 2008-2013. 2007. https://ec.europa.eu/health/ph_overview/Documents/strategy_wp_en.pdf.

7 European Commission Directorate General for Economic and Financial Affairs: The 2012 Ageing Report: economic and budgetary projections for the 27 EU Member States (2010-2060). Brussels, European Commission, May 2, 2012. http://ec.europa.eu/economy_finance/publications/european_economy/2012/ pdf/ee-2012-2_en.pdf (accessed July 12, 2012).

8 Robine JM, Jagger C: The rationale for healthy life years as a structural indicator for the European Commission. Brussels, European Commission, 2005. http://ec.europa.eu/health/ph_information/implement/wp/indicators/docs/ev_20050125_rd01_en.pdf (accessed July 12, 2012).

9 Squeezing out the doctor: the role of physicians at the centre of health care is under pressure. The Economist, June 2, 2012. http://www.economist.com/node/21556227.

10 European Commission: Communication from the Commission to the European Parliament, the Council, the European Economic and Social Committee and the Committee of the Regions of 24 June 2009 on Action against Cancer: European Partnership. Brussels, European Commission, 2009. 